\title{
Absence of pepsinogen A3 gene expression in the gastric mucosa of patients with gastric
}

\section{cancer}

\author{
E J Kuipers, A S Peña, J B A Crusius, J Defize, P van der Stoop, S G M Meuwissen, \\ G Pals
}

\begin{abstract}
Aims-To investigate the expression of pepsinogen $\mathrm{A3}(\mathbf{P g} 3)$ encoding genes in the gastric mucosa of normal controls and subjects with atrophic gastritis and gastric cancer.

Methods-One hundred and fifty nine patients underwent upper gastrointestinal endoscopy with sampling of gastric biopsy specimens and serum. Pg3 isoproteins were determined by electrophoresis in serum and gastric mucosal biopsy specimens. Pg3 encoding genes were assessed by PCR in DNA obtained from peripheral blood.

Results-One hundred and one subjects (82 normal histology/chronic gastritis, 17 atrophic gastritis, two gastric cancer) showed a pepsinogen phenotype with presence of $\mathrm{Pg} 3$ and a corresponding pepsinogen genotype with presence of $\mathbf{P g} 3$ encoding genes. Fifty eight subjects showed a phenotype lacking Pg3. In 39 of them (23 normal histology/chronic gastritis, 11 atrophic gastritis, five gastric cancer), a corresponding genotype without Pg3 encoding genes was found. However, in the remaining 19 subjects (4 normal histology/chronic gastritis, nine atrophic gastritis, six gastric cancer), Pg3 encoding genes were demonstrable in the absence of $\mathrm{Pg} 3$ production.

Conclusions-Unexpressed Pg3 encoding genes can be shown in many cases of atrophic gastritis and gastric cancer, but rarely in healthy controls and subjects with superficial gastritis. The correlation of
\end{abstract}

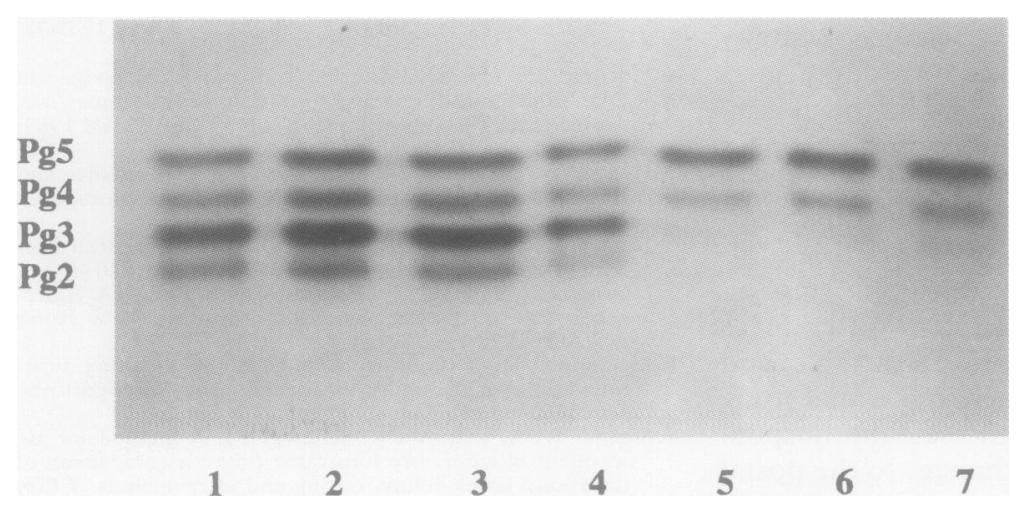

Figure 1 PGA electrophoresis of serum from seven patients, visualized by immunoblotting. Patients 1-4 have dominant Pg3 bands. Patients 5-7 have very low intensity of Pg3. Pg2 is a secondary product of $\mathrm{Pg} 3$ and is therefore absent in patients $5-7$.

atrophic gastritis and gastric cancer with a pepsinogen phenotype lacking Pg3 can be explained by loss of expression of Pg3 encoding genes throughout the complete gastric mucosa. The mechanism of such loss and the importance as a marker for premalignant degeneration have to be elucidated.

(f Clin Pathol 1995;48:376-379)

Keywords: Pepsinogen, gene expression, gastric cancer, polymerase chain reaction.

Pepsinogens are proteases secreted by the chief cells of the gastric mucosa. They can be shown in gastric mucosal biopsy specimens, gastric juice, serum, and urine. Biochemically, discrimination can be made between pepsinogen A (PGA) and pepsinogen C (PGC). With the use of polyacrylamide gel electrophoresis (PAGE) under non-denaturating conditions, PGA and PGC are shown to be composed of serveral different pepsinogen $(\mathrm{Pg})$ isoproteins. ${ }^{1}$ These are called Pg2-5 (PGA), and Pg6 and 7 (PGC) in order of decreasing anodal mobility. ${ }^{2}$ Previous family and population studies of PGA multigene clusters made it possible to identify specific genes encoding the different isozymogens. ${ }^{3}$ In addition, nucleotide sequences of cloned PGA genes were determined. ${ }^{34}$

The determination of a pepsinogen electrophoresis pattern, or so called pepsinogen phenotype, has clinical importance. A clear correlation has been shown between atrophic gastritis or gastric cancer and an electrophoretic pepsinogen phenotype characterised by a weak or absent $\mathrm{Pg} 3$ isozymogen band and a relatively strong Pg5 band" ${ }^{5-10}$ (fig 1). This so called " $a b-$ sent $\mathrm{Pg} 3$ " phenotype (Pg3 ${ }^{-}$phenotype) can be found four to five times as often in cases of atrophic gastritis and gastric cancer as in healthy controls and patients with benign upper gastrointestinal disorders. ${ }^{5}$ The purpose of this study was to gain further insight into the cause of the "absent Pg3" phenotype and its significance in gastric carcinogenesis by a comparison of pepsinogen phenotypes and genotypes in a group of patients with different clinical disorders.

PATIENTS

One hundred and forty six patients $(F=59$, $M=87$ ) were included at referral for diagnostic gastroscopy for reasons of upper abdominal 
complaints. A further 13 cases (seven men, six women) were included in the study of the basis of an endoscopic and histological diagnosis of gastric cancer. The mean (SD) age was 53 (15.3) years, with a range of 22-92 years. Endoscopy was performed with Olympus endoscopes (GIF-Q10,-Q20). Using standard biopsy forceps, specimens were taken from the gastric antrum $(n=2)$, corpus $(n=3)$ and, in case of abnormal lesions, from the abnormal site $(n=5)$ for histology. Haematoxylin-eosin stained $4 \mu \mathrm{m}$ histological slides were assessed according to the Sydney classification. An additional corpus biopsy specimen was taken for pepsinogen phenotype and genotype assessment. A venous blood sample was obtained from all subjects after endoscopy. The protocol was approved by the ethics committee of the Free University Hospital. Oral informed consent was obtained from each subject.

\section{SAMPLE PREPARATION}

Serum samples and biopsy specimens for pepsinogen assessment were kept at $-20^{\circ} \mathrm{C}$ until analysis. Both serum and supernatant of sonified gastric biopsy specimens were treated according to the routine protocol for pepsinogen electrophoresis in our laboratory. ${ }^{112}$ Samples were diluted in electrophoresis buffer up to a volume of $50 \mu \mathrm{l}$. Subsequently, $25 \mu \mathrm{l}$ of stacking gel buffer containing $40 \%$ (wt/vol) sucrose, and $0.1 \mathrm{~g} / 1$ bromophenol blue were added. Bromophenol blue was used to monitor the electrophoresis front.

\section{POLYACRYLAMIDE GEL ELECTROPHORESIS AND IMMUNOBLOTTING}

Electrophoresis of both serum samples and biopsy specimens was performed using nondenaturing polyacrylamide gels, as previously described. ${ }^{1112}$ In brief, electrophoresis of all samples was performed with use of a vertical polyacrylamide slab gel. After electrophoresis, the gels containing the gastric biopsy samples were treated by incubation for 20 minutes at $37^{\circ} \mathrm{C}$ in a solution of $0.1 \mathrm{~mol} / 1 \mathrm{HCl}$ and $2 \%$ bovine haemoglobin, followed by incubation for another 40 minutes in a solution of $0.1 \mathrm{~mol} / 1$ $\mathrm{HCl}$ only. Thereafter these gels were stained for protein during one hour in a solution containing $0.2 \%$ Coomassie brilliant blue R250 in $10 \%(\mathrm{vol} / \mathrm{vol})$ acetic acid and $25 \%(\mathrm{vol} / \mathrm{vol})$

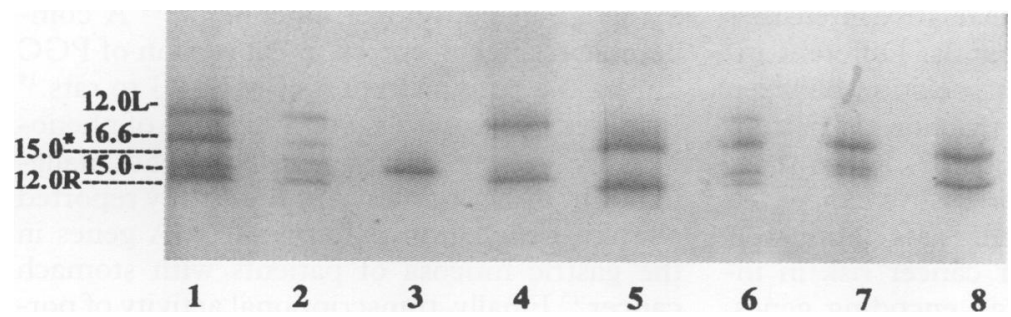

Figure 2 Phastgel electrophoresis of PCR products from the upstream region of the PGA genes. The different PGA genes are indicated on the left (see methods section for nomenclature). Lanes 1,2 and 6-8 are from different patients. Some patients have five or more genes (for example, patients 1 and 2), due to gene duplication. Patient 8 has no Pg3 encoding genes. Lanes 3-5 are from cosmids containing one or two PGA genes; lane $315 \cdot 0^{*}$ gene, lane $412 \cdot 0 \mathrm{~L}$ and 15.0 genes, and lane $512.0 \mathrm{R}$ and 16.6 genes. isopropanol. The gels were destained in $10 \%$ acetic acid.

After PAGE, gels containing the serum samples were treated by electroblotting onto a polyvinylidene difluoride membrane (Immobilon; Millipore). ${ }^{1}$

In case of a weak band at the $\mathrm{Pg} 3$ electrophoresis site, electrophoresis was repeated after incubation of the sample with an anti-Pg3 and anti-Pg5 monoclonal antibody in order to distinguish between $\mathrm{Pg} 3$ and the comigrating secondary product of $\mathrm{Pg} 4$. In this way, a true absence of $\mathrm{Pg} 3$ could be assessed.

\section{POLYMERASE CHAIN REACTION (PCR)}

PGA genes can be distinguished by the length (in kb) of their largest EcoRI generated DNA fragment on Southern blots. ${ }^{3} \mathrm{Pg} 4$ is encoded by a 16.6 and a (very rare) 20.0 gene. $\mathrm{Pg} 5$ is encoded by a 15.0 and a $12.0 \mathrm{~L}$ gene. $\mathrm{Pg} 3$ is encoded by a $15 \cdot 0^{*}$ and a $12 \cdot 0 \mathrm{R}$ gene. The $15 \cdot 0$ and $15 \cdot 0^{*}$ genes can be differentiated by presence of a HindIII restriction site in the 15.0 gene. The two 12.0 genes can be discriminated by presence of an AvaII restriction site in the $12 \cdot 0 \mathrm{R}$ gene. With this knowledge, presence of $\mathrm{Pg} 3$ encoding genes was assessed in sonified gastric mucosal biopsy specimens of each individual.

We used primers 5'-GGCCCTTGTCAATGCTTCAG-3' (sense) and 5'-AGAGGAGCAATGACCGGGAGCTTT-3' (antisense) to amplify part of the upstream region of the PGA genes. ${ }^{413}$ Sequence differences in this region were used to assess presence of the different PGA genes.

PCR was performed in an Air Thermocycler (type 1605, Idaho Technology), using $0 \cdot 1 \mathrm{U}$ of Taq polymerase per $25 \mu$ l reaction volume (Supertaq) with the reaction buffer supplied by the manufacturer (HT Biotechnology), $10 \mathrm{pmol}$ of each primer and $200 \mu \mathrm{M}$ dNTP's. The temperature profile was $5 \mathrm{~s} 93^{\circ} \mathrm{C} ; 5 \mathrm{~s} 56^{\circ} \mathrm{C}$; $30 \mathrm{~s} 72^{\circ} \mathrm{C}$ for 30 cycles. PCR products were analysed by electrophoresis on Phastsystem ${ }^{\mathrm{TM}}$ (Pharmacia) (fig 2). The different PGA genes can be recognised as separate bands, due to small differences in DNA sequence and size.

\section{STATISTICAL ANALYSIS}

Univariate statistical analysis was performed with use of Fisher's exact test. A p value $<0.05$ was considered significant.

\section{Results}

DIAGNOSIS

Endoscopy and histology revealed no relevant abnormalities in 109 subjects: 58 normal findings, 51 chronic gastritis without atrophy (together defined as "controls"). Thirty seven subjects had histological signs of moderate to severe atrophic gastritis of the gastric body. Thirteen subjects had gastric cancer (table).

\section{PG3 PHENOTYPE}

$\mathrm{Pg} 3$ isoprotein production $\left(\mathrm{Pg} 3^{+}\right.$phenotype) was demonstrated in 101 subjects: 82 of the 
Pepsinogen electrophoresis and pepsinogen A-3 gene assessment in relation to diagnosis in 159 patients.

\begin{tabular}{llll}
\hline & \multicolumn{2}{l}{ Pg3 genotype genes } & \\
\cline { 2 - 3 } Diagnosis & Present & Absent & Pg3 phenotype \\
\hline $\begin{array}{l}\text { Controls } \\
\text { (n=109) }\end{array}$ & 82 & 0 & Protein present \\
$\begin{array}{l}\text { Atrophic gastritis } \\
(\mathrm{n}=37)\end{array}$ & 4 & 23 & Protein absent \\
$\begin{array}{l}\text { Gastric cancer } \\
(\mathrm{n}=13)\end{array}$ & 9 & 0 & Protein present \\
\hline
\end{tabular}

controls ( $75 \%$ of all control subjects), 17 cases with atrophic gastritis (46\%), and only two gastric cancer cases (15\%) (table). A Pg3phenotype was thus found in $25 \%$ of the control population, which was in significant contrast with the prevalence of such a phenotype in $54 \%$ of subjects with atrophic gastritis $(\mathrm{p}=$ 0.0019 ; Fisher exact test) and $85 \%$ of gastric cancer cases $(p<0.0001)$. The difference between atrophic gastritis and gastric cancer cases was not statistically significant $(p=0 \cdot 095)$.

\section{PG3 GENOTYPE}

The presence of $\mathrm{Pg} 3$ encoding genes $\left(\mathrm{Pg} 3^{+}\right.$ genotype) was demonstrated in all 101 cases with a $\mathrm{Pg} 3^{+}$phenotype (table).

The remaining 58 cases had a $\mathrm{Pg} 3^{-}$phenotype. In 39 of them, this was shown to be due to absence of $\mathrm{Pg} 3$ encoding genes $\left(\mathrm{Pg} 3^{-}\right.$ genotype): 23 controls ( $21 \%$ of all control subjects), 11 atrophic gastritis (30\%), and five gastric cancer cases (38\%). These differences in prevalence of a $\mathrm{Pg}^{-}$genotype in the three subgroups were not statistically significant $(0.173<p<0.730$ for the various comparisons). In contrast, in the remaining 19 subjects with a $\mathrm{Pg} 3^{-}$phenotype, a $\mathrm{Pg} 3^{+}$genotype was found: four controls ( $5 \%$ of all 86 control subjects with a $\mathrm{Pg} 3^{+}$genotype), nine subjects with atrophic gastritis $(9 / 26=35 \%)$, and six subjects with gastric cancer $(6 / 8=75 \%)$. Thus the presence of unexpressed $\mathrm{Pg} 3$ encoding genes occurred significantly more often in cases with atrophic gastritis $(p=0.0002)$ or gastric cancer $(p<0.0001)$, when compared with controls. The difference between the first two subgroups did not reach statistical significance $(\mathrm{p}=0 \cdot 10)$.

\section{Discussion}

The electrophoretic patterns of pepsinogen A show large interindividual differences with respect to the presence and the relative intensities of the specific isoprotein bands. Different investigators have noted an association between presence of a specific electrophoresis pattern characterised by absence of $\mathrm{Pg} 3$, and a diagnosis of atrophic gastritis or gastric cancer. ${ }^{5910}$ It was unknown whether this association was due to a hereditary higher cancer risk in individuals with a lack of $\mathrm{Pg} 3$ encoding genes, or to a secondary loss of isoprotein production in the process of development of atrophy and cancer. Determination of the pepsinogen phenotype, which can be performed on a serum sample, has been put forward as a screening tool to detect subjects at risk for gastric malignancy. ${ }^{5}$ Unfortunately this test lacks sensitivity for the purpose of screening large populations when used without other indices. ${ }^{5}$

In the present study, we confirm the earlier reports of a significant correlation of a $\mathrm{Pg} 3^{-}$ phenotype with atrophic gastritis and gastric cancer, by showing such a phenotype in $25 \%$ of the control subjects versus $54-85 \%$ of subjects with atrophy or cancer. These percentages are higher than those reported in the earlier studies. This could be due to a variety of factors such as the use of sera (with less secondary $\mathrm{Pg} 4$ products at the $\mathrm{Pg} 3$ electrophoresis site) instead of gastric biopsy specimens, and repetition of phenotyping after incubation with the monoclonal antibody. Both methods make it easier to detect non-producers of $\mathrm{Pg} 3$ among those individuals with weak electrophoretic bands at the Pg3 site. More importantly, our study shows for the first time that there is no corresponding correlation of a $\mathrm{Pg}^{-}$genotype with atrophy and cancer of the stomach. These results thus reject the hypothesis of a hereditary gastic cancer risk in subjects with a $\mathrm{Pg} 3^{-}$genotype. In contrast, a $\mathrm{Pg} 3^{-}$phenotype in atrophic gastritis and gastric cancer subjects can result from the specific loss of expression of $\mathrm{Pg} 3$ encoding genes, as we show in 15 cases with atrophy or cancer, and in a further four cases without histological abnormalities. Follow up is necessary to evaluate eventual development of atrophy in these four cases. Previous research has shown that serum pepsinogen phenotypes match the gastric mucosal pepsinogen pattern. ${ }^{1}$ This order is of major importance in those 19 cases with a discrepant result between assessment of the pepsinogen phenotype and genotype. A total absence of the $\mathrm{Pg} 3$ isoprotein in serum in these cases means that the loss of expression of $\mathrm{Pg} 3$ encoding genes not only occurs in the areas of severest atrophy or near the surroundings of a cancerous lesion, but also throughout the complete gastric mucosa. This leads to the important suggestion that in these cases gastric cancer may develop in a mucosa with a diffusely occurring change in gene expression. During the development of atrophy and gastric cancer, a selective loss of production of $\mathrm{Pg} 3$ may occur.

This is in accordance with previous experiments. In the presence of the methylating agent $\mathrm{N}^{\prime}$-methyl-N'-nitro- $\mathrm{N}$-nitrosoguanidine (MNNG), cultures of human gastric chief cells showed a specific decrease of $\mathrm{Pg} 3$ production without affecting $\mathrm{Pg} 4$ and $\mathrm{Pg} 5$, thus leading to a change in pepsinogen phenotype. ${ }^{14} \mathrm{~A}$ comparable change occurred in expression of PGC during the administration of MNNG to rats. ${ }^{14}$ It should be stressed that this change of phenotype occurred before the development of malignancy in these animals. Another study reported altered methylation patterns of PGA genes in the gastric mucosa of patients with stomach cancer. ${ }^{15}$ Finally, transcriptional activity of porcine PGA promotor in chief cells from pig was completely abolished by in vitro methylation. ${ }^{16}$ Alterations in expression of $\mathrm{Pg} 3$ encoding genes, as demonstrated by a $\mathrm{Pg} 3^{-}$phenotype and a $\mathrm{Pg} 3^{+}$genotype, or by a change in the 
Pg3 phenotype during follow up, might thus be a marker of subsequent premalignant degeneration. The mechanism of this loss of $\mathrm{Pg} 3$ expression is still unclear. In accordance with the results of the addition of MNNG to cultured chief cells, ${ }^{14}$ it might be proposed that expression of $\mathrm{Pg} 3$ genes is more susceptible to methylation than that of other pepsinogen encoding genes. The contribution of specific risk factors for gastric cancer, like $H$ pylori infection, to the absent $\mathrm{Pg} 3$ phenotype has to be studied.

In conclusion, based on the results of our study we postulate that a selective loss of production of pepsinogen-3 may be a sign of subsequent premalignant degeneration. This hypothesis should be tested since it may be of importance in screening programmes for gastric cancer. Finally, the mechanism underlying the loss of expression of these genes in the gastric mucosa has to be elucidated.

RT Taggart, PhD, Wayne State University, Detroit, Michigan, USA is kindly acknowledged for the delivery of the monoclonal antibody II-219 directed against $\mathrm{Pg} 3$ and $\mathrm{Pg} 5$. This study was made possible by financial support of the Netherlands Digestive Diseases Foundation. The preliminary results of the study were presented as a poster at the annual meeting of the American Gastroenterology Association, May 1992, San Francisco.

1 Zwiers A, Crusius B, Pals G, Donker AJM, Meuwissen $S G M$, ten Kate RW. Human pepsinogen A isozymogen patterns in serum and gastric mucosa. Gastroentemlogy 1990;99:1576-80.

2 Eriksson AW, Foltmann B, Frants RR, Gedde-Dahl TJ, Samloff IM, Taggart RT. Nomenclature Committee reSamloff IM, Taggart RT. Nomenclature
port. Prog Clin Biol Res 1985;173:23-30.

3 Bebelman JP, Evers MPJ, Zelle B, Bank R, Pronk JC Meuwissen SGM, et al. Family and population studies on the human pepsinogen A multigene family. Hum Genet 1989;82:142-6.

4 Evers MPJ, Zelle B, Bebelman JP, van Beusechem V, Kraakman L, Hoffer MJV, et al. Nucleotide sequence comparison of five human pepsinogen A (PGA) genes; evolution of the PGA multigene family. Genomics $1989 ; 4: 232-9$.

5 Westerveld BD, Pals G, Lamers CBHW, Defize J, Pronk JC, Frants RR, et al. Clinical significance of pepsinogen $A$ isozymogens, serum pepsinogen $A$ and $C$ levels, and A isozymogens, serum pepsinogen A and C

6 Samloff IM, Varis K, Ihamäki T, Siurala M, Rotter JI. Relationships among serum pepsinogen I, serum pepsinogen II, and gastric mucosal histology: a study in relatives of patients with pernicious anemia. Gastroenterology 1982;83:204-9.

7 Westerveld BD, Pals G, Defize J, Pronk JC, Frants RR Kreuning $\mathrm{J}$, et al. Qualitative and quantitative determinations of pepsinogen $I$ in gastric cancer and premalignant changes of the stomach. Prog Clin Biol Res 1985; 173:201-212.

8 Westerveld BD, Pals G, Defize, J, Pronk JC, Frants RR, Ooms EMC, et al. Pepsinogen A polymorphism in gastric mucosa and urine, with special reference to patients with mucosa and urine, with special reference to

9 Whitecross DP, Armstrong C, Clarke AD, Piper DW. The pepsinogens of human gastric mucosa. Gut 1973;14:850 5.

10 Ellis A, Hughes S, McConnell RB. Gastric neoplasms and pepsinogen phenotypes. Br $\mathcal{F}$ Cancer 1982;46:289-90

11 Pals G, Westerveld BD, Defize J, Pronk JC, Brand H Flipse $\mathrm{M}$, et al. Discrepancies between gastric mucosa and urinary pepsinogen $A$ patterns and in vitro synthesis and secretion of human pepsinogen. Dig Dis Sci 1988;33: 135-43.

12 Zwiers A, Toonstra C, Pals G, Donker AJM, Meuwissen SGM, ten Kate RW. Immunoblot technique to visualize serum pepsinogen $\mathrm{A}$ isozymogen patterns. $f$ Clin Pathol 1990;43:871-4.

13 Takahashi K. Gene structures of pepsinogen A and C. Scand f Clin Lab Invest 1992;52 (suppl 210):97-110.

14 Defize J, Derodra JK, Riddell RH, Hunt RH. Changes in rat and human pepsinogen phenotypes induced by $\mathrm{N}^{\prime}$ methyl-N'-nitro-N-nitrosoguanidine. Cancer 1988;62: 1958-61.

15 Ichinose M, Miki K, Wong RN, Tatematsu M, Furihata C, Konishi T, et al. Methylation and expression of human pepsinogen genes in normal tissues and their alteration in stomach cancer. $7 p n$ ₹ Cancer Rese 1991;82:686-92.

16 Meijerink PHS, Bebelman JP, Oldenburg AM, Defize Planta RJ, Eriksson AW, et al. Gastric chief cell-specific transcription of the pepsinogen A gene in the pig. Eur $f$ transcription of the pepsinogen
Biochem 1993;213:1283-96. 